\title{
Spinal tolerance and dependence: Some observations on the role of spinal $N$-methyl-D-aspartate receptors and phosphorylation in the loss of opioid analgesic responses
}

\author{
Tony L Yaksh PhD, Xiao-Ying Hua MD PhD
}

TL Yaksh, X-Y Hua.

Spinal tolerance and dependence: Some observations on the role of spinal $N$-methyl-D-aspartate receptors and phosphorylation in the loss of opioid analgesic responses.

Pain Res Manage 2000;5(1):33-39.

The continuous delivery of opiates can lead to a reduction in analgesic effects. In humans, as in other animals, some component of this change in sensitivity seems likely to have a strong pharmacodynamic component. Such loss of effect, deemed to be tolerance in the present article, can be readily demonstrated in animals with repeated bolus and continuous intrathecal infusion of mu and delta opioids and alpha- 2 adrenergic agonists. Research has shown that this loss of effect can be diminished by concurrent treatment with $N$-methyl-D-aspartate (NMDA) receptor antagonists and by the suppression of the activity of spinal protein kinase $\mathrm{C}$ (PKC). This suggests in part the probable role of PKC-mediated phosphorylation in the right shift in the dose-effect curves observed with continuous opiate or adrenergic exposure. Importantly, this right shift is seen to occur in parallel with an increase in the phosphorylating activity in the dorsal horn and in the expression of several PKC isozymes. The target of this phosphorylation is not certain. Phosphorylation of the NMDA receptor enhances its functionality, while phosphorylation of the opioid receptor or associated channels seems to diminish their activity or to enhance internalization. While the focus is on several specific components, the accumulating data emphasize the biological complexity of these changes in spinal drug reactivity.

Key Words: NMDA; Protein kinase C; Spinal tolerance
Tolérance et dépendance d'origine médullaire : quelques observations sur le rôle des récepteurs médullaires de $N$-méthyl-D-aspartate et de la phosphorylation dans la diminution de la réaction aux analgésiques opiö̈des

RÉSUMÉ : L'administration continue d'opiacés peut mener à une diminution de l'effet analgésique. Chez les humains, comme chez d'autres animaux, certains éléments liés à ce changement de sensibilité semblent avoir une forte composante pharmacodynamique. La perte d'effet, considérée ici comme de la tolérance, peut s'observer facilement chez les animaux qui reçoivent des bolus répétés ou des perfusions continues intrathécales d'opioïdes mu et delta ou d'agonistes alpha-2 adrénergiques. La recherche a montré que l'administration concomitante d'inhibiteurs des récepteurs de $N$-méthyl-D-aspartate (NMDA) et la suppression de l'activité de la protéine-kinase C (PKC) médullaire peuvent réduire cette perte d'effet. Cela donne à penser, en partie, que la phosphorylation médiée par la PKC joue probablement un rôle dans le glissement vers la droite des courbes dose-effet, observé avec l'administration continue d'opiacés ou de substances adrénergiques. Point important à souligner, ce déplacement vers la droite est parallèle à l'augmentation de l'activité de phosphorylation dans la corne supérieure et dans l'expression de plusieurs iso-enzymes de la PKC. On ne comprend pas trop bien quelle cible vise la phosphorylation. D'une part, elle augmente le fonctionnement des récepteurs de NMDA, mais, d'autre part, elle semble diminuer l'activité ou améliorer l'endocytose des récepteurs opioïdes et des voies associées. Pendant que l'intérêt se porte sur plusieurs composantes précises, les données accumulées mettent nettement en évidence la complexité biologique des changements de réactivité médullaire aux médicaments.

Department of Anesthesiology, University of California, San Diego, California, USA

Correspondence and reprints: Dr Tony L Yaksh, University of California, San Diego, Department of Anesthesiology, Anesthesiology Research Laboratory,

9500 Gilman Drive, La Jolla, California 92093-0818 USA. Telephone 619-543-3597, fax 619-543-6070, e-mail tyaksh@ucsd.edu 
ANALGESIC TOLERANCE

Antinociceptive effects produced by systemically (1-3) or spinally $(4,5)$ delivered mu and delta opiates in animal models show a rapid decrement over an interval of hours to days. Spinal delivery of alpha-2 adrenergic agonists also produces antinociception. Chronic exposure results in a time-dependent decrement of activity (6). This loss of response to both classes of drug is characterized by a reduction in the effect produced by a given dose of that drug; an increase in the dose required to produce a given analgesic effect (eg, a shift of the dose-effect curve to the right); a decreasing maximum response $(5,7,8)$; little cross-tolerance between agents that act at separate receptors (eg, mu versus delta [9]; mu versus alpha-2 [6,10]); an asymmetrical cross-tolerance between agents that are believed to act at the same receptor but differ in intrinsic activity (eg, sufentanil versus morphine [11], dexmedetomidine versus clonidine [12]); and after extended spinal exposure, significant hyperalgesia and spontaneous agitation evoked by withdrawal of the agonist by abstinence or by treatment with the respective antagonists (12-14). The signs of mu opiate withdrawal are suppressed by spinal alpha-2 agonists.

In humans, the issue of opiate analgesic tolerance is considerably more complex and not as well characterized as in the preclinical model. Even with extended intervals of spinal or systemic delivery in chronic pain patients, long intervals of stable drug requirement are observed (15-17). Nevertheless, moderate exposure to opiates postoperatively (18) or in cancer patients with stable pain over seven days (19) results in a modest loss of analgesic effect in humans. Spinal delivery of opiates to humans with chronic pain is often accompanied by an increase in the required dose over the period of infusion. In a retrospective examination of 163 cancer patients receiving continuous intrathecal infusion, an increase in the mean infusion concentration was noted (20). Inspection of the data revealed that some patients showed significant increases while many others did not. This is further emphasized when the same data are plotted as the median and 25 th to 75 th percentiles. The majority of patients showed no additional increase in the required dose after the first month. Plotting the individual increase in dosage in 33 patients over six months revealed that 21 displayed less than a threefold increase in starting dose. Thus, while many patients achieved protracted pain relief with spinal drugs, most patients showed some degree of dose increase.

Failure to see rapid changes in opiate consumption over time in clinically treated pain patients has been attributed to the possibility that the concurrent nature of the pain stimulus itself may alter tolerance development. Well defined preclinical studies have suggested that concurrent pain states (eg, inescapable pressure, arthritis or, in animals, an irritant in the paw) attenuate the loss of opiate responsiveness with chronic exposure (21-24). In another study, loss of sensitivity to systemic opiates was enhanced by arthritic states or by stressors (25). The role of ongoing pain states in analgesic tolerance is thus surprisingly unclear, although interactions between afferent input and spinal biochemistry are evident.

\section{POTENTIAL MECHANISMS UNDERLYING DOSE ESCALATION}

Several factors may account for the loss of analgesic effect with continuous exposure and/or the increase in dose of drug required to produce a given magnitude of analgesia.

\section{Change in pharmacokinetics}

The abrupt return of pain in patients having achieved initial results from continuous spinal drug administration may result from changes in drug delivery or diffusion, including catheter removal; development of spinal cord compression; miscalculation of the dose; kinking or disconnection of catheters; development of a pseudomeningocele along the catheter or catheter investment, leading to a restricted spinal distribution of the injected drug; and change in drug spinal distribution secondary to catheter investment. These effects lead to an increase in the dose of agent required to produce a given degree of analgesia.

\section{Change in pain intensity}

Rapid increases in opiate dose requirements may reflect changes in the clinical state (eg, tumour metastasis and dysesthetic pain states). Alterations in the magnitude of the stimulus may result from changes in tumour mass, the presence of metastasis or development of pain states incidental to primary pathology (eg, bowel stasis, urinary retention, or septic bladder or kidney). Metastasis may lead to the distribution of disease to dermatomes that were previously unaffected (eg, fascia or bone), resulting in an enhanced activation of small afferents. Such increases predictably result in a rightward shift in the dose response curve for the analgesic agent (26-29). Preclinical studies have indicated that the degree of right shift is inversely proportional to the intrinsic activity of the agonist (26). As stimulus intensity rises, the fraction of receptors that must be occupied is elevated and, theoretically, the intensity of the stimulus may be such that at near full receptor occupancy, the agent is unable to block transmission (ie, the agent technically becomes a partial agonist).

\section{Change in pain mechanisms}

Animal models have shown that different pain states may display a differential modulation by different classes of agents $(30,31)$. Emergent pain states may result from evolving injuries to nerves (eg, developing tumours, radiation injury or chemotherapy). In such pain states, the effective stimulus may be the activation of low threshold mechanoreceptors (A-beta fibers) (32). Such input may activate systems that are not regulated in so efficacious a fashion by opiates as that input generated by small afferents (33). In systematic studies, the efficacy of epidural morphine was found to be as follows: somatic greater than visceral greater than radiating pain (34). Emergent neuropathies may thus result in the development of pain states that are less sensitive to opiates, though they may display sensitivity to other classes of agents, such as alpha- 2 receptor agonists or N-type voltage- 
sensitive calcium channels (31). Such changes would serve to produce a right shift in the opiate dose effect relationship.

\section{Change in psychosocial status}

The evolution of pain states is frequently accompanied by significant changes in emotional status, the development of primary states of depression, and changes in lifestyle and coping mechanisms. Such alterations must be considered when significant changes in treatment efficacy are observed.

\section{Change in pharmacodynamics (tolerance)}

In well defined animal models, ongoing exposure to opiates results in a reduction in the responsiveness to the agent. Such changes occur in the absence of alterations in drug levels. While learning (ie, drug conditioning) can contribute to such changes, the loss of effect observed in chronic delivery studies occurs in the absence of prior training. This phenomenon in spinal drug delivery models is not secondary to decreased concentrations (eg, increased metabolism or clearance). Moreover, the phenomenon is often characterized by a right shift in the dose-effect curve with a decreasing maximum, a property suggestive of a reduction in the number of coupled receptors.

\section{PHARMACODYNAMIC ISSUES RELATED TO TOLERANCE}

As noted above, the continued exposure of the spinal cord to mu and delta opioid or alpha- 2 adrenergic agonists (toleragen) results in a progressive loss of effect over time and a right shift in the dose-effect curve for a probe drug of the respective receptor class when assessed after extended exposure. While the mechanisms of this phenomenon are not understood, there is considerable evidence that the phenomenon may reflect complex changes in local system function.

\section{SPINAL $N$-METHYL-D-ASPARTATE RECEPTOR: TOLERANCE AND WITHDRAWAL}

One component of the change in system function relates to the original observation by Trujillo and Akil (35) that the loss of response to systemic opioids may be diminished by the concurrent delivery of antagonists for the $N$-methylD-aspartate (NMDA) glutamate receptors. The development of tolerance to mu opioid agonists delivered spinally (ie, reduced effect over time and/or a right shift of the probe dose-response curve) is diminished by a concurrent blockade of the spinal NMDA ionophore (36-39). Although blockade of the spinal NMDA receptor alters tolerance, tolerance to spinally infused opioids occurs in the absence of increases in spinal glutamate release (14). This suggests that the role played by the spinal glutamatergic system reflects an enhanced responsiveness of the NMDA receptor and not an increase in release.

While spinal glutamate release was largely unaltered during the development of tolerance, it showed a large increase during withdrawal. This enhanced release correlated with the onset of hyperalgesia. Importantly, the hyperalgesia and agitation were reversed by the spinal delivery of NMDA antagonists and alpha-2 adrenoreceptor agonists. This apparent relationship between spinal withdrawal signs and glutamate release is consistent with the observation that spinal glutamate receptor activation induces agitation and a hyperalgesic state.

An interesting corollary to the above observations is that if activation of glutamate receptors facilitates tolerance, repeated withdrawal as produced by episodic naloxone administration would enhance the magnitude of tolerance because of increased periodic increases in glutamate release. Repetitive daily withdrawal led to an enhanced tolerance, and there was a progressive appearance of hyperalgesia and enhanced spinal glutamate release during the daily naloxone precipitated withdrawal (40). It should be noted that periodic withdrawal is an intrinsic component of studies in which bolus drug delivery is employed to provide opiate exposure. Such studies often report the evolution of a hyperalgesic state that is reversed by intrathecal NMDA receptor antagonism (39). Such hyperalgesia is not noted during the course of continuous spinal mu and alpha-2 infusion.

\section{SPINAL SITES OF OPIATE AND ALPHA-2 ADRENERGIC ACTION DEMONSTRATING TOLERANCE}

Opiates may act at both primary afferent sites and at nonprimary afferent sites in the dorsal horn. Accordingly, it is likely that inhibition of evoked small afferent transmitter release (eg, substance $\mathrm{P}[\mathrm{SP}]$ ) and the activation of dorsal horn neurons demonstrate a reduced inhibition with chronic spinal mu and alpha-2 agonist exposure. Chronic exposure of dorsal root ganglion cells results in the opiate effect being converted from an inhibitory effect to an excitatory effect mediated by Gs protein $(41,42)$. This suggests a tolerance mediated at the level of the primary afferent. It is hypothesized that during withdrawal, there is a corresponding increase in afferent terminal excitability, as measured by SP release. Although this has not been directly assessed, behavioural hyperalgesia during withdrawal is attenuated by intrathecal neurokinin-1 antagonists (43), consistent with the observation that intrathecal SP produces hyperalgesia (27).

In spinal release studies, small afferent input leads to an increase in spinal glutamate and prostaglandin-2 release, which is blocked by morphine (44). Because morphine has an action on afferent terminals, the locus of morphine action in this model is not certain. In contrast, intrathecal SP evokes spinal glutamate and prostaglandin release (45). Because of the association of the neurokinin-1 site with postsynaptic sites (46), this release is hypothesized to be from nonprimary afferents. This direct 'postafferent' effect should also display a loss of effect with continued agonist exposure. Further, during withdrawal, it is likely that these transmitters display an increase in release. As noted above, previous work has demonstrated that there is an increase in spinal glutamate and prostaglandin-2 release during withdrawal (14). 


\section{SPINAL OPIATE AND ADRENERGIC RECEPTOR ACTIONS AND PHOSPHORYLATION}

An important consequence of NMDA receptor activation is an increase in intracellular calcium and the activation of a variety of kinases. Protein kinase C (PKC) inhibitors diminish tolerance associated with spinal delivery of mu agonists and with approaches that prevent translocation of PKC $(47,48)$. Spinal delivery of protein kinase A inhibitors in mice diminished the activity of morphine in tolerant animals $(49,50)$. As with spinal nociceptive processing, the changes in spinal opiate sensitivity reflect a net balance of the constitutive activity of kinases and phosphatase $(49,51)$.

There are several mechanisms by which a phosphorylation state may influence mu opiate action with chronic exposure. Mu opiate agonists and phorbol esters induce mu receptor desensitization, and this correlates with receptor phosphorylation (52). Importantly, phorbol ester, but not agonist-induced phosphorylation and desensitization, is blocked by the PKC inhibitor staurosporine (53). Thus, while consensus sites for PKC activity exist on the mu and alpha-2 receptor (52), the agonist-induced desensitization in at least one model is not mediated by PKC (54). An alternative route of phosphorylation is the $\mathrm{G}$ protein-coupled kinases. These enzymes can readily phosphorylate agonistoccupied (but not unoccupied or antagonist-occupied) receptors (55). Thus, inhibition of voltage-dependent calcium channels mediated by alpha-2 receptor desensitizes slowly with agonist exposure, and this desensitization is mediated by $\mathrm{G}$ protein-coupled kinases (56). Inhibition of calcineurin or activating PKC (both increasing phosphorylation) reduces pertussis toxin-sensitive $\mathrm{G}$ protein $(\mathrm{G}[\mathrm{PTX}])$-mediated inhibition of the N-type calcium channel $(57,58)$. This effect appears to be selective because it is not seen for muscarinic receptor-mediated inhibition of the $\mathrm{N}$-type calcium channel (mediated though a non-G[PTX] linkage) (58). Because the inhibitory effects of mu and alpha-2 receptors are coupled through PTX-sensitive linkage, these spinal receptors are expected to behave similarly. Given that phosphorylation diminishes the actions of the alpha- 2 receptor, increased phosphorylating activity through an inositol triphosphate pathway by mu opiate receptor occupancy may provide an explanation as to why a modest cross-tolerance exists between mu and the alpha-2 receptor (6). Accordingly, inhibition of phosphorylation may prevent the modest crosstolerance otherwise observed. On the other hand, the link between the mu receptor and calcium channels is unlike the PKC-mediated linkages that couple mu receptor to NMDA channels in dorsal horn neurons $(59,60)$ and the alpha-2 receptor to calcium channels in dorsal root ganglion neurons (61). For the mu receptor, a tight localization of the signalling pathway between receptor and channel was noted and hypothesized to reflect a direct link by a G protein (62).

An important intracellular linkage has been demonstrated between mu opiate and the NMDA receptor and mediated by phosphorylation $(59,60)$. Mu opiates, through PKC, lead to an increased inositol triphosphate level $(63,64)$. This coupling yields increased intracellular calcium derived from in- tracellular storage sites. Calcium leads to translocation of PKC to the plasma membrane. This leads to phosphorylation of the NMDA receptor, increasing the probability of channel openings and reducing the voltage-dependent magnesium block. This yields an enhanced NMDA response, which in turn leads to increased intracellular calcium.

A consequence of the above thinking is that in the presence of continued opiate exposure the cell is in a 'facilitated' state because of the increased effects associated with the phosphorylated NMDA receptor. Rohde and colleagues (65) demonstrated that the activation of spinal c-fos by formalin in the paw is exaggerated in morphine-tolerant animals. In recent work (71), we showed that on day 5 of morphine infusion, bolus intrathecal chelerythrine or GF109203X (GF), another PKC inhibitor, reversed in a dose-dependent fashion the loss of probe morphine effect otherwise observed when examined on day 6 ( $24 \mathrm{~h}$ after termination of the five-day morphine infusion sequence). The inactive homologue of GF, bisindolymaleimide V, was without effect (66). These results are consistent with the results of other laboratories that have reported that $\mathrm{PKC}$ inhibitors are able to diminish tolerance development (47,67-71). These results suggest that chronic morphine infusion may increase spinal phosphorylating activity, and this increase is exacerbated by withdrawal. This likelihood is confirmed by our observation that on day six, after termination of intrathecal morphine infusion on day five, there was a twofold increase in dorsal horn, but not ventral horn, PKC phosphorylating activity. Importantly, the intrathecal dose of PKC inhibitor that reversed morphine tolerance was sufficient to block the increase in dorsal horn PKC-mediated phosphorylating activity (as measured by phosphorylation of a PKC-selective substrate). Importantly, these effects were not noted after an acute bolus of intrathecal morphine. Using ${ }^{3} \mathrm{H}$-phorbol-12,13-dibutyrate binding, Mayer and colleagues (66) showed that daily spinal injection of morphine leads to an increase in membrane-bound PKC, particularly in spinal laminae I and II.

These results jointly suggest that, during opiate exposure, the change in spinal responsiveness may reflect the activation of spinal PKC. Of particular interest, not only is there an increase in kinase activation (as suggested by the increased phosphorylating activity) and the appearance of membranebound PKC, but an increased expression of PKCalpha/gamma was also observed, as measured by Western blots (66). This suggests an upregulation of phosphorylating capacity $24 \mathrm{~h}$ after termination of opiate infusion. These results suggest that, during the course of opiate exposure, activation of $\mathrm{PKC}$ is in part responsible for the loss of effect that occurs with continuous morphine exposure.

\section{PHOSPHORYLATING ENZYMES RELEVANT TO TOLERANCE}

Several PKC isozymes have been described. Which ones are functionally relevant to nociceptive processing is a subject of considerable interest. As noted above, morphine infusion resulted in an increased dorsal horn expression of both PKCalpha/gamma. Mao and colleagues (47) reported that daily 
repeated spinal morphine administration in rats is associated with an increase in the membrane bound PKC-gamma isoform. This isozyme is located in populations of neurons in the substantia gelatinosa, and knockout mice studies have emphasized the importance of this isozyme to the development of hyperalgesia (72), a phenomenon that also occurs in withdrawal. Nevertheless, we suspect that the increased phosphorylating activity noted above likely reflects upon an activation of a variety of PKC isoforms. In this regard, it should be emphasized that there is only a modest (ie, 5\%) overlap between neurons expressing mu opioid receptors and PKC-gamma (73). It thus seems unlikely that the entire phenomenon of tolerance could be associated with that specific population of neurons (although they might mediate some or all of the hyperpathia).

\section{ROLE OF SPINAL PHOSPHORYLATION}

The mechanisms whereby phosphorylation alters spinal tolerance are likely to be complicated. Based on the data reviewed in the preceding sections, two broad classes of alternatives are considered.

\section{Changes in nonopiate receptor function}

Activation of kinases results in the phosphorylation of numerous membrane proteins that constitute receptor channels and enzymes that regulate neuronal excitability. One example of the effect of such phosphorylation is the assigned importance of the NMDA ionophore to the tolerance process. The studies with NMDA antagonists outlined above emphasize the importance of the NMDA receptor in spinal opiate tolerance. Phosphorylation of the NMDA receptor increases the functionality of the NMDA ionophore, which, accordingly, serves to increase calcium flux (74). This positive feedback would thus serve to enhance opiate receptor phosphorylation, with an attendant decrease in mu receptor function. Not incidentally, phosphorylation of the NMDA receptor appears to play an important role in the development of hyperalgesia (see above).

\section{REFERENCES}

1. Askitopoulou H, Whitwam JG, Al-Khudhairi D, Chakrabarti M, Bower S, Hull CJ. Acute tolerance to fentanyl during anesthesia in dogs. Anesthesiology 1985;63:255-61.

2. Cox BM, Ginsburg M, Osman $\mathrm{OH}$. Acute tolerance to narcotic analgesic drugs in rats. Br J Pharmacol 1968;33:245-56.

3. Martin WR, Eades CG. Demonstration of tolerance and physical dependence in the dog following short term infusion of morphine. J Pharmacol Exp Ther 1961;133:262-70.

4. Stevens CW, Yaksh TL. Magnitude of opioid dependence after continuous intrathecal infusion of mu- and delta-selective opioids in the rat. Eur J Pharmacol 1989;166:467-72.

5. Stevens CW, Yaksh TL. Time course characteristics of tolerance development to continuously infused antinociceptive agents in rat spinal cord. J Pharmacol Exp Ther 1989;251:216-23.

6. Stevens CW, Monasky MS, Yaksh TL. Spinal infusion of opiate and alpha-2 agonists in rats: tolerance and cross-tolerance studies. J Pharmacol Exp Ther 1988;244:63-70.

7. Stevens CW, Yaksh TL. Potency of infused spinal antinociceptive agents is inversely related to magnitude of tolerance after continuous infusion. J Pharmacol Exp Ther 1989;250:1-8.

\section{Opiate receptor-effector coupling}

Preservation of the analgesic effect of chronic spinal morphine by PKC inhibition may reflect changes in receptoreffector coupling. Mu opioid receptors inhibit adenylyl cyclase activity through $\mathrm{Gi}$, a glutamyl transpeptidase membrane-bound protein, decreasing cAMP formation (75). Decreased cAMP levels activate PKC, which then phosphorylates the mu receptor-coupled $G$ protein. This linkage would thereby serve to suppress the receptor-evoked inhibition of adenylate cyclase $(76,77)$. G protein-coupled receptor kinases may specifically phosphorylate and uncouple agonist-activated receptors and facilitate their interaction with beta-arrestins $(53,78,79)$, by which the receptors may be further uncoupled from their $\mathrm{G}$ protein (78).

\section{CONCLUSIONS}

The present comments focus on the importance of the cascade that is initiated in part by the release of glutamate, the activation of local kinases and the ensuing phosphorylation of local components that alter the ability of the opiate occupancy of the receptor to diminish cellular excitability in the face of a high intensity afferent discharge (eg, nociception). As indicated, while we have focused on two players, the NMDA receptor and PKC, the probable contribution of other excitatory transmitters (such as SP, purines and the like) and other phosphorylating enzymes are likely to prove to be of considerable importance. On the other hand, that the studies have shown the effects to be robust and are observed to be associated with parallel results observed with alpha-2 agonists acting at another G-coupled protein receptor provides some sense that this cascade may contribute broadly to the overall mechanisms by which such downregulation in pharmacological effect is observed.

ACKNOWLEDGEMENTS: This work was supported in part by funds from DA02110.

8. Stevens CW, Yaksh TL. Studies of morphine and D-ala2-D-leu5-enkephalin (DADLE) cross-tolerance after continuous intrathecal infusion in the rat. Anesthesiology 1992;76:596-603.

9. Russell RD, Leslie JB, Su YF, Watkins WD, Chang KJ. Continuous intrathecal opioid analgesia: tolerance and cross-tolerance of mu and delta spinal opioid receptors. J Pharmacol Exp Ther 1987;240:150-8.

10. Yaksh TL, Reddy SV. Studies in the primate on the analgetic effects associated with intrathecal actions of opiates, alpha-adrenergic agonists and baclofen. Anesthesiology 1981;54:451-67.

11. Sosnowski M, Yaksh TL. Differential cross-tolerance between intrathecal morphine and sufentanil in the rat. Anesthesiology 1990;73:1141-7.

12. Takano Y, Yaksh TL. Chronic spinal infusion of dexmedetomidine, ST-91 and clonidine: spinal alpha 2 adrenoceptor subtypes and intrinsic activity. J Pharmacol Exp Ther 1993;264:327-35.

13. Stevens CW, Yaksh TL. Opioid dependence after continuous intrathecal infusion of mu and delta opioids in the rat. NIDA Res Monogr 1989;95:544-5.

14. Jhamandas KH, Marsala M, Ibuki T, Yaksh TL. Spinal amino acid 
release and precipitated withdrawal in rats chronically infused with spinal morphine. J Neurosci 1996;16:2758-66.

15. Twycross RG. Opioid analgesics in cancer pain: current practice and controversies. Cancer Surveys 1988;7:29-53.

16. Foley KM. Opioids. Neurol Clin 1993;11:503-22.

17. Coyle N, Adelhardt J, Foley KM, Portenoy RK. Character of terminal illness in the advanced cancer patient: pain and other symptoms during the last four weeks of life. J Pain Symptom Manage 1990;5:83-93.

18. McQuay HJ, Bullingham RE, Moore RA. Acute opiate tolerance in man. Life Sci 1981;28:2513-7.

19. Houde RW, Wallenstein SL, Beaver WT. Evaluation of analgesics in cancer pain. In: Lasagna L, ed. International Encyclopaedia of Pharmacology and Therapeutics. New York: Pergamon Press, 1966.

20. Yaksh TL, Onofrio BM. Retrospective consideration of the doses of morphine given intrathecally by chronic infusion in 163 patients by 19 physicians. Pain 1987;31:211-23.

21. Abbott FV, Melzack R, Leber BF. Morphine analgesia and tolerance in the tail-flick and formalin tests: dose-response relationships. Pharmacol Biochem Behav 1982;17:1213-9.

22. Colpaert FC, Niemegeers CJ, Janssen PA. Nociceptive stimulation prevents development of tolerance to narcotic analgesia. Eur J Pharmacol 1978;49:335-6.

23. Colpaert FC. Can chronic pain be suppressed despite purported tolerance to narcotic analgesia? Life Sci 1979;24:1201-9.

24. Colpaert FC, Niemegeers CJ, Janssen PA, Maroli AN. The effects of prior fentanyl administration and of pain on fentanyl analgesia: tolerance to and enhancement of narcotic analgesia. J Pharmacol Exp Ther 1980;213:418-24.

25. Kayser V, Neil A, Guilbaud G. Repeated low doses of morphine induce a rapid tolerance in arthritic rats but a potentiation of opiate analgesia in normal animals. Brain Res 1986;383:392-6.

26. Dirig DM, Yaksh TL. Differential right shifts in the dose-response curve for intrathecal morphine and sufentanil as a function of stimulus intensity. Pain 1995;62:321-8.

27. Dirig DM, Yaksh TL. Thermal hyperalgesia in rat evoked by intrathecal substance $\mathrm{P}$ at multiple stimulus intensities reflects an increase in the gain of nociceptive processing. Neurosci Lett 1996;220:93-6.

28. Saeki S, Yaksh TL. Suppression by spinal alpha-2 agonists of motor and autonomic responses evoked by low- and high-intensity thermal stimuli. J Pharmacol Exp Ther 1992;260:795-802.

29. Saeki S, Yaksh TL. Suppression of nociceptive responses by spinal mu opioid agonists: effects of stimulus intensity and agonist efficacy. Anesth Analg 1993;77:265-74.

30. Yaksh TL. Preclinical models of nociception. In: Yaksh TL, Lynch C III, Zapol W, Maze M, Biebuyck JF, Saidman LJ, eds. Anesthesia: Biologic Foundations, vol I. Philadelphia: Lippincott-Raven Publishers, 1997:685-718.

31. Yaksh TL. Spinal systems and pain processing: development of novel analgesic drugs with mechanistically defined models. Trends Pharmacol Sci 1999;20:329-37.

32. Treede RD, Meyer RA, Raja SN, Campbell JN. Peripheral and central mechanisms of cutaneous hyperalgesia. Prog Neurobiol 1992;38:397-421.

33. Yaksh TL, Chaplan SR. Physiology and pharmacology of neuropathic pain. In: Wallace M, Dunn J, Yaksh TL, eds. Anesthesiology Clinics of North America. Philadelphia: WB Saunders, 1997:335-53.

34. Samuelsson H, Hedner T. Pain characterization in cancer patients and the analgetic response to epidural morphine. Pain 1991;46:3-8.

35. Trujillo KA, Akil H. Inhibition of morphine tolerance and dependence by the NMDA receptor antagonist MK-801. Science 1991;251:85-7.

36. Dunbar S, Yaksh TL. Concurrent spinal infusion of MK801 blocks spinal tolerance and dependence induced by chronic intrathecal morphine in the rat. Anesthesiology 1996;84:1177-88. [published erratum appears in Anesthesiology 1996;85:695]

37. Dunbar SA, Pulai IJ. Repetitive opioid abstinence causes progressive hyperalgesia sensitive to $N$-methyl-D-aspartate receptor blockade in the rat. J Pharmacol Exp Ther 1998;284:678-86.
38. Kest B, Mogil JS, Shamgar BE, Kao B, Liebeskind JC, Marek P. The NMDA receptor antagonist MK-801 protects against the development of morphine tolerance after intrathecal administration. Proc West Pharmacol Soc 1993;36:307-10.

39. Mao J, Price DD, Mayer DJ. Thermal hyperalgesia in association with the development of morphine tolerance in rats: roles of excitatory amino acid receptors and protein kinase C. J Neurosci 1994;14:2301-12.

40. Ibuki T, Dunbar SA, Yaksh TL. Effect of transient naloxone antagonism on tolerance development in rats receiving continuous spinal morphine infusion. Pain 1997;70:125-32.

41. Crain SM, Shen KF, Chalazonitis A. Opioids excite rather than inhibit sensory neurons after chronic opioid exposure of spinal cord-ganglion cultures. Brain Res 1988;455:99-109.

42. Crain SM, Shen KF. Opioids can evoke direct receptor-mediated excitatory effects on sensory neurons. Trends Pharmacol Sci 1990;11:77-81.

43. Buccafusco JJ, Shuster LC. Effect of intrathecal pretreatment with the neurokinin receptor antagonist CP-99994 on the expression of naloxone-precipitated morphine withdrawal symptoms. Brain Res Bull 1997;43:321-6.

44. Malmberg AB, Yaksh TL. The effect of morphine on formalin-evoked behaviour and spinal release of excitatory amino acids and prostaglandin E2 using microdialysis in conscious rats. Br J Pharmacol 1995;114:1069-75.

45. Hua XY, Chen P, Marsala M, Yaksh TL. Intrathecal substance P-induced thermal hyperalgesia and spinal release of prostaglandin E2 and amino acids. Neuroscience 1999;89:525-34.

46. Mantyh PW, Allen CJ, Ghilardi JR, et al. Rapid endocytosis of a G protein-coupled receptor: substance $P$ evoked internalization of its receptor in the rat striatum in vivo. Proc Natl Acad Sci (USA) 1995;92:2622-6.

47. Mao J, Price DD, Phillips LL, Lu J, Mayer DJ. Increases in protein kinase $\mathrm{C}$ gamma immunoreactivity in the spinal cord of rats associated with tolerance to the analgesic effects of morphine. Brain Res 1995;677:257-67.

48. Mayer DJ, Mao J, Price DD. The development of morphine tolerance and dependence is associated with translocation of protein kinase $\mathrm{C}$. Pain 1995;61:365-74.

49. Bernstein MA, Welch SP. Inhibition of protein phosphatases alters the expression of morphine tolerance in mice. Eur J Pharmacol 1998;341:173-7.

50. Bernstein MA, Welch SP. Effects of spinal versus supraspinal administration of cyclic nucleotide-dependent protein kinase inhibitors on morphine tolerance in mice. Drug Alcohol Depend 1997;44:41-6.

51. Wang L, Medina VM, Rivera M, Gintzler AR. Relevance of phosphorylation state to opioid responsiveness in opiate naive and tolerant/dependent tissue. Brain Res 1996;723:61-9.

52. Yu Y, Zhang L, Yin X, Sun H, Uhl GR, Wang JB. Mu opioid receptor phosphorylation, desensitization, and ligand efficacy. J Biol Chem 1997;272:28869-74.

53. Zhang L, Yu Y, Mackin S, Weight FF, Uhl GR, Wang JB. Differential mu opiate receptor phosphorylation and desensitization induced by agonists and phorbol esters. J Biol Chem 1996;271:11449-54.

54. Pei G, Kieffer BL, Lefkowitz RJ, Freedman NJ. Agonist-dependent phosphorylation of the mouse delta-opioid receptor: involvement of $\mathrm{G}$ protein-coupled receptor kinases but not protein kinase C. Mol Pharmacol 1995;48:173-7.

55. Inglese J, Freedman NJ, Koch WJ, Lefkowitz RJ. Structure and mechanism of the $\mathrm{G}$ protein-coupled receptor kinases. J Biol Chem 1993;268:23735-8.

56. Diverse-Pierluissi M, Inglese J, Stoffel RH, Lefkowitz RJ, Dunlap K. $\mathrm{G}$ protein-coupled receptor kinase mediates desensitization of norepinephrine-induced $\mathrm{Ca} 2+$ channel inhibition. Neuron 1996;16:579-85.

57. Zhu Y, Ikeda SR. Modulation of $\mathrm{Ca}(2+)$-channel currents by protein kinase $\mathrm{C}$ in adult rat sympathetic neurons. J Neurophysiol 1994;72:1549-60. 
58. Zhu Y, Yakel JL. Calcineurin modulates G protein-mediated inhibition of N-type calcium channels in rat sympathetic neurons. J Neurophysiol 1997;78:1161-5.

59. Chen L, Huang LY. Sustained potentiation of NMDA receptormediated glutamate responses through activation of protein kinase $\mathrm{C}$ by a mu opioid. Neuron 1991;7:319-26.

60. Chen L, Huang LY. Protein kinase C reduces Mg2+ block of NMDA-receptor channels as a mechanism of modulation. Nature 1992;356:521-3.

61. Diversé-Pierluissi M, Dunlap K. Distinct, convergent second messenger pathways modulate neuronal calcium currents. Neuron 1993;10:753-60.

62. Wilding TJ, Womack MD, McCleskey EW. Fast, local signal transduction between the mu opioid receptor and $\mathrm{Ca} 2+$ channels. J Neurosci 1995;15:4124-32.

63. Johnson PS, Wang JB, Wang WF, Uhl GR. Expressed mu opiate receptor couples to adenylate cyclase and phosphatidyl inositol turnover. Neuroreport 1994;5:507-9.

64. Tsu RC, Wong YH. Gi-mediated stimulation of type II adenylyl cyclase is augmented by Gq-coupled receptor activation and phorbol ester treatment. J Neurosci 1996;16:1317-23.

65. Rohde DS, Detweiler DJ, Basbaum AI. Formalin-evoked Fos expression in spinal cord is enhanced in morphine-tolerant rats. Brain Res 1997;766:93-100.

66. Mayer DJ, Mao J, Price DD. The association of neuropathic pain, morphine tolerance and dependence, and the translocation of protein kinase C. NIDA Res Monogr 1995; 147:269-98.

67. Narita M, Feng Y, Makimura M, Hoskins B, Ho IK. A protein kinase inhibitor, H-7, inhibits the development of tolerance to opioid antinociception. Eur J Pharmacol 1994;271:543-5.

68. Narita M, Makimura M, Feng Y, Hoskins B, Ho IK. Influence of chronic morphine treatment on protein kinase $\mathrm{C}$ activity: comparison with butorphanol and implication for opioid tolerance. Brain Res 1994;650:175-9.
69. Narita M, Mizoguchi H, Tseng LF. Inhibition of protein kinase C, but not of protein kinase A, blocks the development of acute antinociceptive tolerance to an intrathecally administered mu-opioid receptor agonist in the mouse. Eur J Pharmacol 1995;280:R1-3.

70. Narita M, Mizoguchi H, Kampine JP, Tseng LF. Role of protein kinase $\mathrm{C}$ in desensitization of spinal delta-opioid-mediated antinociception in the mouse. Br J Pharmacol 1996;118:1829-35.

71. Granados-Soto V, Kalcheva I, Hua X-Y, Newton A, Yaksh TL. Spinal PKC activity and expression: Role in tolerance produced by continuous spinal morphine infusion. Pain (In press)

72. Malmberg AB, Chen C, Tonegawa S, Basbaum AI. Preserved acute pain and reduced neuropathic pain in mice lacking PKCgamma. Science 1997;278:279-83.

73. Polgár E, Fowler JH, McGill MM, Todd AJ. The types of neuron which contain protein kinase $\mathrm{C}$ gamma in rat spinal cord. Brain Res 1999;833:71-80.

74. Cerne R, Rusin KI, Randic M. Enhancement of the $N$-methyl-D-aspartate response in spinal dorsal horn neurons by cAMP-dependent protein kinase. Neurosci Lett 1993;161:124-8.

75. Bachrach U, Benalal D, Reches A. Morphine inhibits cyclic AMP-dependent protein kinase and ornithine decarboxylase activities in neuroblastoma X glioma hybrid cells. Life Sci 1979;25:1879-83.

76. Katada T, Gilman AG, Watanabe Y, Bauer S, Jakobs KH. Protein kinase $\mathrm{C}$ phosphorylates the inhibitory guanine-nucleotide-binding regulatory component and apparently suppresses its function in hormonal inhibition of adenylate cyclase. Eur J Biochem 1985;151:431-7.

77. Nestler EJ. Cellular responses to chronic treatment with drugs of abuse. Crit Rev Neurobiol 1993;7:23-39.

78. Lefkowitz RJ. G protein-coupled receptor kinases. Cell 1993;74:409-12.

79. Ferguson SS, Barak LS, Zhang J, Caron MG. G-protein-coupled receptor regulation: role of G-protein-coupled receptor kinases and arrestins. Can J Physiol Pharmacol 1996;74:1095-110. 


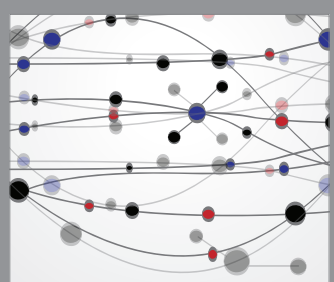

The Scientific World Journal
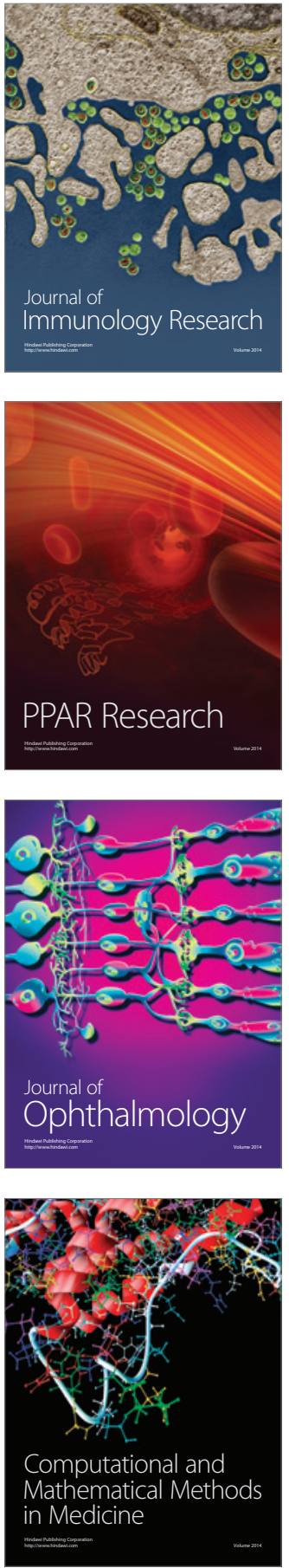

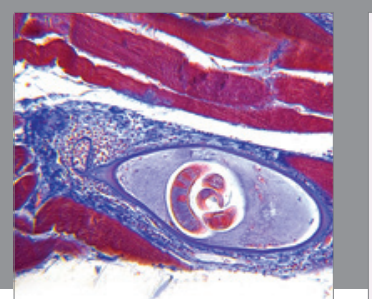

Gastroenterology Research and Practice

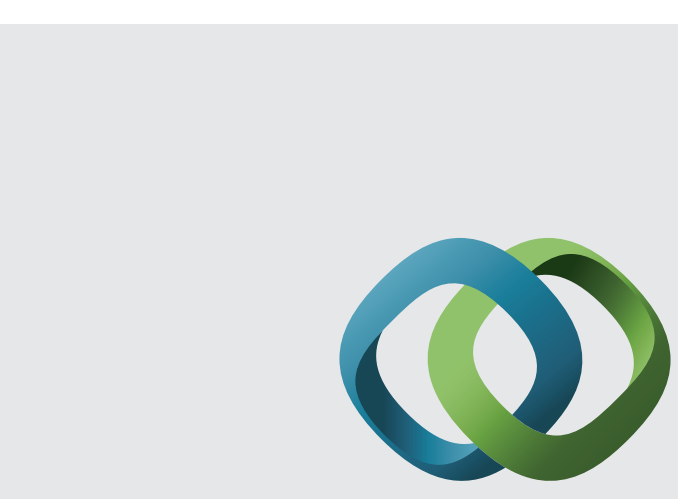

\section{Hindawi}

Submit your manuscripts at

http://www.hindawi.com
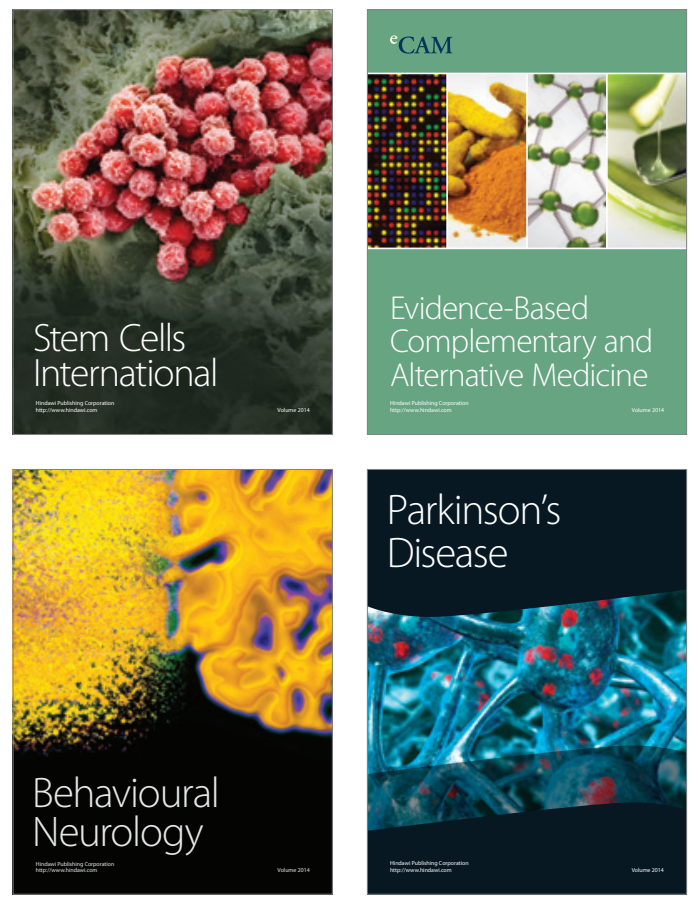
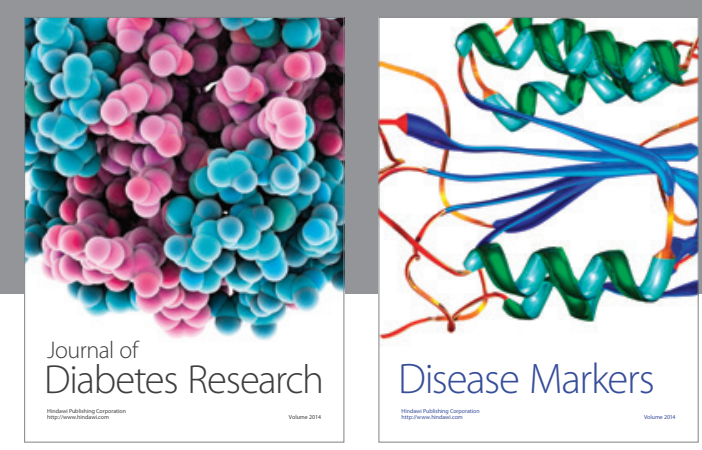

Disease Markers
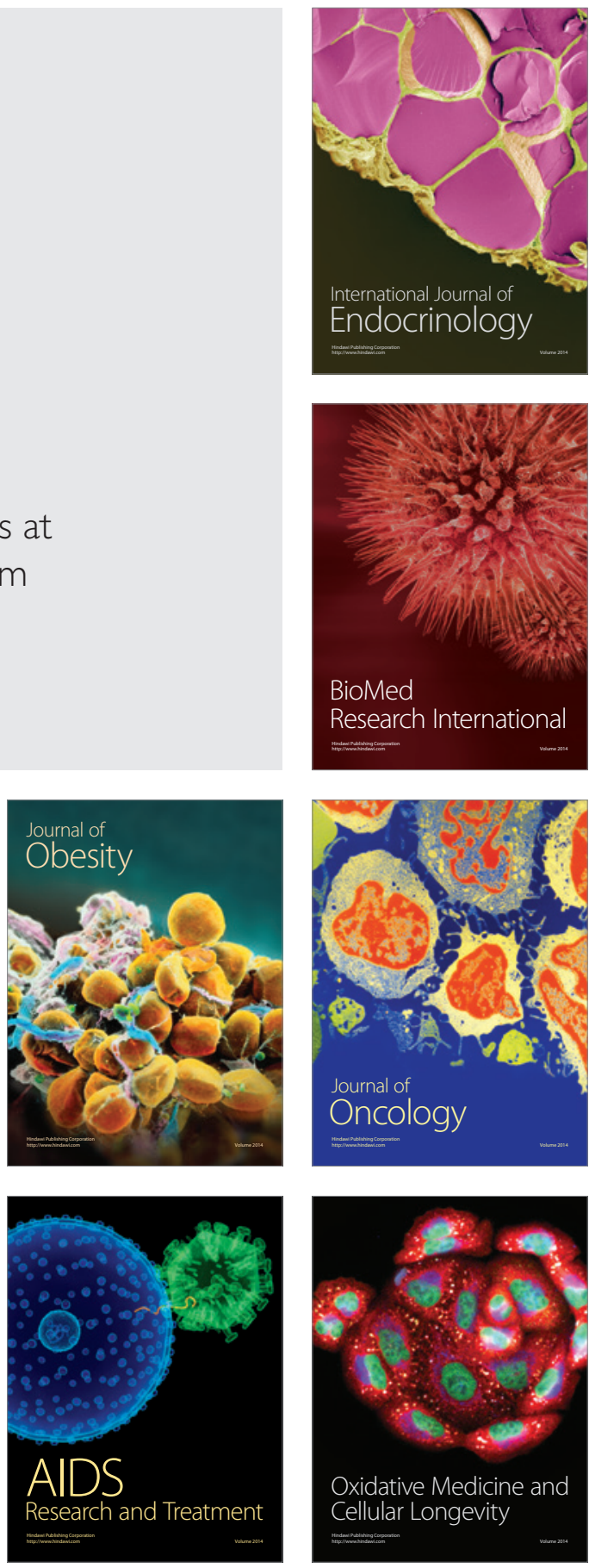